\title{
Yoga and Mind-Body Medicine
}

\author{
Indira Anand* \\ BA Hons Ayurvedic Medicine University, London
}

Submission: April 13, 2019; Published: May 14, 2019

*Corresponding author: Indira Anand, BA Hons Ayurvedic Medicine University, Member British Institute of Marmapuncture, London

Abstract

The rapid growth and development of the holistic health field indicates that our understanding of health and its needs are changing in fundamental ways. Yet, there are two inter-related crucial concepts, which are at the very core of Yoga that must be integrated more fully into holistic healthcare.

Keywords: Mind-Body connection; Prana Vidya; Swara Yoga; niyama; asana; pranayama; pratyahara; dharna; Dhyana; Samadhi; prajnapradha; Yoga Nidra; psycho-somatic diseases

\section{Introduction}

The rapid growth and development of the holistic health field indicates that our understanding of health and its needs are changing in fundamental ways. Yet, there are two inter-related crucial concepts, which are at the very core of Yoga that must be integrated more fully into holistic healthcare to take it to the next stage

a. The Mind-Body connection - to work on the mind to effect biological changes in the body.

b. The manipulation of the Energy Body through simpler yogic practices of Prana Vidya and Swara Yoga.

\section{The Mind-Body Connection}

The mind is organically related to the physical body. We change our biology by what we think and feel. Depression and despair can destroy the immune system, raise the risk of heart attacks and cancer while love, contentment and joy will keep us healthy and extend our life. Other negative emotions like anger, jealousy and hatred also act as poisons for our etheric and astral bodies and adversely affect the channels of vital energy, resulting in malfunctioning of the energy centres and the endocrine system. Our mind influences every cell in the body. It is obvious therefore, that we need to pay more attention to the connection between biology and psychology when dealing with healthcare. Unfortunately, Modern Medicine is failing to recognise this adequately and make good use of the alternatives available.

Although Yoga has become so popular all over the world, there is very little understanding about its true potential in healthcare.
The overwhelming focus is on yoga asanas or physical postures, which is only one limb of 'Ashtanga Yoga'. Yoga according to Patanjali, is a methodical effort to attain perfection, through control of the different elements of human nature - physical, mental and psychical. The physical body, the active will and the understanding mind are to be brought under control and freed from their impurities. The eight limbs of yoga (yama, niyama, asana, pranayama, pratyahara, dharna, dhyana and Samadhi) help to purify the mind and the body. When we combine certain physical exercises with mental practices, we create a way to tap into the inner resources of the Mind-Body connection. The simple way to get this to work is to allow yourself to get into a meditative state and get your body to relax, while you instruct the mind. The more one is able to achieve and maintain the meditative state through the last four limbs of yogic practices, the more one is able to remove the deeper ingrained complexes from the three states of the mind - conscious, subconscious and unconscious. When satva (mind) gets devoid of impurities (tamas and rajas) yoga is perfected as Caraka says - 'then the psyche being purified, shines like the solar disc.' (CS.Sa.5.14-17).

The mind is the main vehicle we use for all that we do, yet few if any of us know how to use and care for it properly. All psychological and many physical problems are nothing more than a wrong use of the mind (prajnapradha), which arises from ignorance of what mind is and how to use the mind. If we know that the mind is an instrument, and we use it as such by being its master, we will be surprised by how much we can achieve. By gaining control of our minds we will no longer be dominated 
by the impulses coming from the senses and conditioning of the external world and will cease to be victims of our minds. The yogic techniques of pratyahara or introversion help to control the mind and Yoga Nidra is the ideal vehicle for bringing deeprooted negative samsakaras to the surface and direct the mind to replace them with desirable traits by making appropriate autosuggestion and/or resolve at the right time during the practice. Only if we change our deepest thoughts can we really change ourselves and get beyond the limitations of the mind.

\section{Yoga Nidra}

Yoga nidra is essentially a method of pratyahara (introversion) wherein awareness is progressively withdrawn from the external world, the body, the process of breathing, the conscious mind and finally the subconscious mind. As the nervous energy is withdrawn from the sensory channels and a state of pratyahara is attained, psychosomatic balance is restored spontaneously, and this energy is redirected for healing and rejuvenation of overtaxed tissues, glands and organs. One of the most common ailments in the modern society is tension or stress - be it muscular, mental or emotional, which is also at the root of most cardio-vascular problems. Yoga Nidra or psychic sleep is a more efficient and effective way of removing these tensions and providing psychic and physiological rest and rejuvenation than conventional sleep or any other practice. A single 25-30 minutes session of yoga nidra is said to be as restful as 2 hours of conventional sleep. Most psycho-somatic diseases also arise from tensions in the body and mind which modern medical science is ill-equipped to tackle. Its value as both a curative and a palliative has been investigated in recent years in many research centres around the world, with extremely favourable results. It has been found useful in both acute and chronic conditions, especially in degenerative and stress related conditions such as hypertension, coronary disease and arthritis. Diseases with a high psychosomatic component such as asthma, peptic ulcers and migraine headache respond favourably to yoga nidra therapy. It has also proved successful in treating insomnia, drug addiction and alcoholism.

Yoga nidra has its most widespread application as a preventive measure to be practised by healthy, active people as a means of purifying the mind, relieving accumulated tensions and preventing psycho-somatic diseases. It is easy to practise at your own convenience by following pre-recorded instructions and can be made more potent by using a 'healing or a characterbuilding resolve'.

\section{Meditation (Dharana \& Dhyana)}

Now that meditation has entered mainstream Western cultural experience, researchers have applied scientific measurement to the subjective experience of silence and meditation. They have discovered that the physiological state of the meditators undergoes definite shifts toward more efficient functioning - lowered respiration, reduced oxygen consumption and decreased metabolic rate. The most significant conclusion worth reporting is that hormonal imbalance associated with stress, and known to speed up with the ageing process, is also reversed with regular meditation. Concentration practices can make the consciousness very refined and strengthen the will power. The mind can be introverted and made one-pointed at will. Concentrated energy is also very potent in self-healing or healing others. It is said that in the state of concentration the mind is like a laser beam as opposed to an ordinary light bulb. It has also been established that long-term meditators can have biological age between 5-12 years younger than their chronological age (Figure 1).

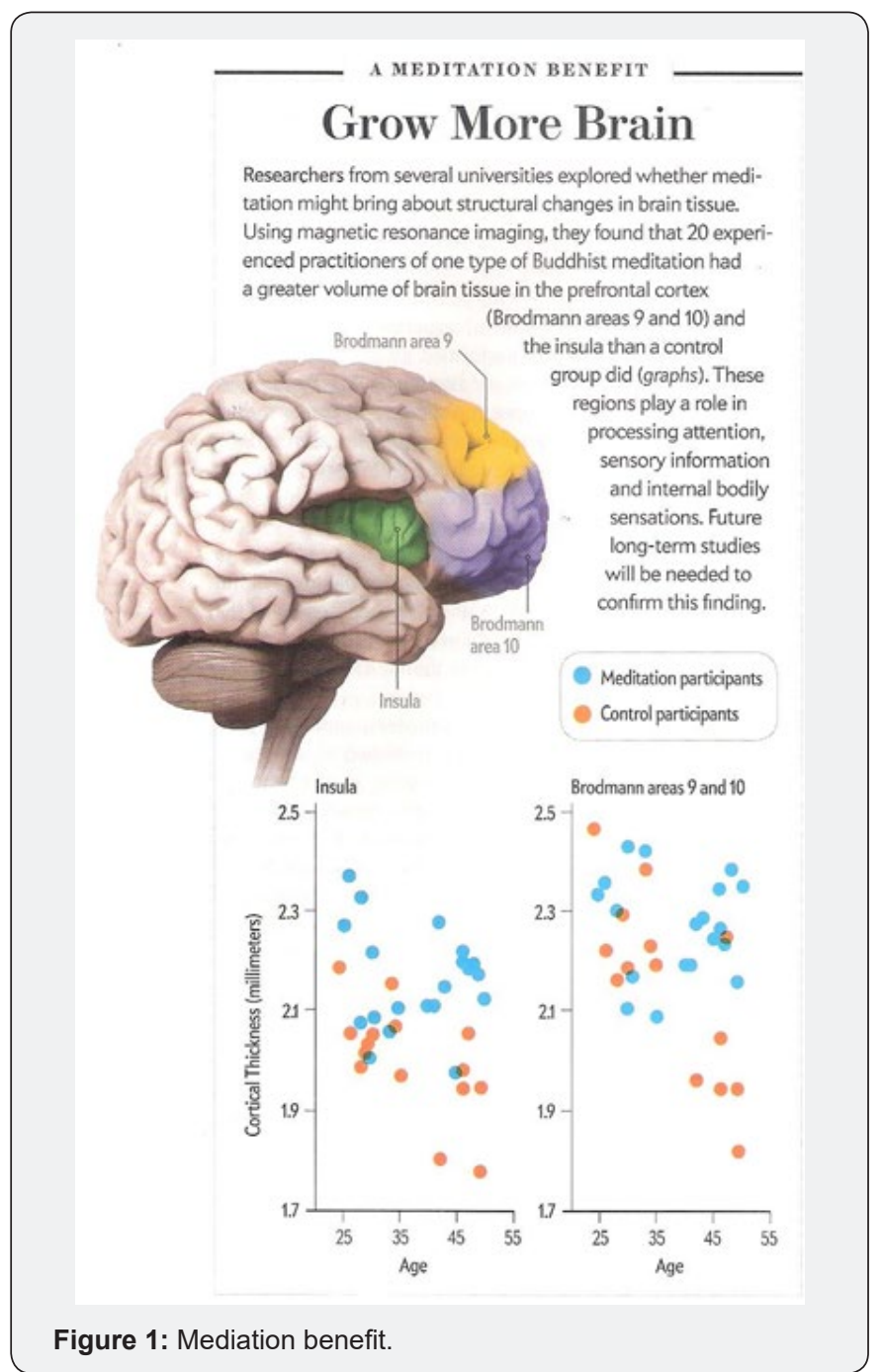

For nearly 15 years more than 100 monastics and lay practitioners of Buddhism and a large number of beginning meditators have participated in scientific experiments at the University of Wisconsin-Madison and at least 19 other universities to prove that meditation produces significant changes in both the function and structure of the brains of experienced practitioners. These studies are starting to demonstrate that contemplative practices may have a substantive impact on biological processes critical for physical health. Even with the requisite cautions, 
research on meditation provides new insights into methods of mental training that have the potential to enhance human health and well-being. (The Neuroscience of Meditation, Scientific American, Nov 2014, Vol 311, Number 5)

\section{Use of Prana Vidya (The Art \& Science of Healing Oneself and Others)}

Prana is all embracing universal life force. The physical body is a storehouse of pranic energy. Each fibre of the body relates to prana by a complex system of energy channels. Thus, the functioning of the physical body is directly related to the quality and quantum of energy flowing within the pranic body. Some oriental sages realised that prana could be expanded or decreased at will and directed and manipulated at will to keep the physical body healthy and young. The therapeutic objective of Marmapuncture and Acupuncture is to restore free flow of prana in the energy channels. But a practitioner of Prana Vidya can move prana using nothing more than attention, for at a deep level attention or awareness and prana are synonymous. The use of prana for healing is so important that it should not be overlooked in any treatment. It is universally agreed that the more prana we have, the more vital our mental and bodily processes. The body's main source of prana is through the breath, which on a gross level brings in oxygen and on a subtle level brings in life energy.

When breathing is refined, slow and regular, the circulation of prana is reaching all levels of body and mind, promoting a state of complete balance. Breath is the junction point between mind, body and spirit. Every change of mental state and feelings is first reflected in the breath and then in the body. This phenomenon also works in reverse - changing the breathing pattern also causes altered emotions. Most yoga practitioners have some idea of how various parnayamas can be used to influence different functions in the body but very few, if any, know much about Prana Vidya.

Prana Vidya practices are an important but not very widely known example of energy healing. They gradually expand the quantum of prana within the body. Energy blocks are removed as prana is moved up and down the nadis or pranic channels. As energy is liberated, it becomes available for distribution to nourish the organs, muscles, bones, cells and atoms. Negative states of mind and emotional tensions are overcome when prana flows freely and in abundance. The psychological state is reflective of the underlying pranic condition, and thus by directing the flow of prana the mind becomes tranquil and calm. Once complete mastery is gained over the flow of prana, the entire body-mind is completely revitalised to such an extent that there is a sense of being reborn.

For pranic healing practices to be effective, it is necessary to have awakened the vision of prana shakti - the dormant energy force. Charging one's own body or that of another with prana should only take place once the healer or practitioner has experienced genuine pranic awakening. Healing can only happen through the pranic body. Just as voltage of electricity can be increased, the store of prana in the body can be increased. Using intense concentration, one-pointed awareness and visualisation, psychic energy is circulated through specific pranic channels in the body in such a way that this generates vast amount of pranic energy, which can then be directed to the weak areas.

\section{Prana Nidra}

Prana Nidra is a unique practice in that it serves the dual purpose of bringing about pratyahara (withdrawal of senses from external stimuli or introversion) as well as sensitising the practitioner to the experience of prana, which is especially useful in Prana Vidya. Visualisation of prana as streams of light particles that flow within the energy channels intensifies the effects of each practice. The practice of Prana Nidra is designed to bring the experience of the energy body of pranamaya kosha, to our conscious awareness. Pranmaya kosha represents the vital energy that animates the physical body or the annamaya kosha and vitalises the mind or the manomaya kosha. It is useful as a physical therapy, as a mental therapy and useful in changing one's perspectives and lifestyle. Like Yoga Nidra it can also be practised at one's convenience by using pre-recorded commentary.

\section{Swar Yoga}

The literal translation of swara is the sound of one's own breath. Swara is the flow of prana, through the nostrils - a very subtle and vital aspect of the breath. Swara Yoga is a complete science with enormous applications. In this paper we can only deal with its everyday use in healthcare. It is not widely known that the active nostril changes approximately every 60 to 90 minutes. This rhythm regulates all the psychological and physiological processes in the body. In the human body the three swaras (through the left, right and both nostrils) correspond to the three major systems - Mind -Chitta, life force - prana and soul - atma. Mind controls the sensory nerves; prana controls the five organs of action and atma or the soul is the overall controller. In its simplest form, attention to right or left nostril breathing could help so many health conditions. Patients suffering from kapha diseases like obesity, edema, muscle stiffness and paralysis should focus on right nostril breathing, which is energising, works on the left side of the brain and controls physical activity.

Right nostril breathing also helps to overcome sleepiness, dullness and fatigue. Patients suffering from diseases of heat like fevers, wasting diseases, ulcers, paralysis, loss of body weight etc should emphasise left nostril breathing, which is cooling and calming, stimulates the right side of the brain and controls mental activity. It is also useful in conditions of hyperactivity of the mind, including insomnia, restlessness and nervous agitation. By balancing the right and left nostril breathing through pranayama and other techniques, one can optimise one's productivity, using the whole brain which can prove helpful in many other ways. 
Manipulating the swara according to requirement is not difficult and could be so helpful in everyday life [1-8].

\section{Conclusion}

Alongside spiritual advancement, physical and mental therapy is one of yoga's most commendable achievements. It is excellent for psychological and mental disorders because of its specific action on the mind through deep relaxation and meditation. What makes it so powerful and effective is the fact that it works on the holistic principles of harmony and unification and because of the balance it creates in the nervous and endocrine systems and organs of the body. Yoga has succeeded as an alternative form of therapy in diseases such as asthma, diabetes, blood pressure, arthritis, digestive disorders and other ailments of a chronic and constitutional nature, where modern medicine is still struggling to achieve satisfactory results.

In the past the wisdom and techniques of esoteric yogic practices of Swara Yoga, Prana Vidya and many others, which teach us how to expand and direct prana to achieve desired physical, mental and spiritual results, were restricted to an initiated few. Today they are widely accessible and if experimented with more widely, they could revolutionise our understanding of health and its management. Scientifically minded people often dismiss all holistic ideas as metaphysical nonsense. Nevertheless, widespread attempts are being made all around the globe to combine neuroscience, emotional intelligence and energy medicine into one integrated whole. It is widely accepted that enduring physical health is entwined with emotional and mental wellbeing, and there is now growing recognition of the fact that psychological well-being is itself deeply connected with a positive spiritual experience of life. Biochemicals like endorphins, adrenalin and serotonin which are both influenced by and have an immense influence on an individual's mental, emotional and physical state are being widely talked about for their psychological, energetic and spiritual implications. If we are willing to explore the unseen levels of our bodies using esoteric yogic practices, we can tap into the immense creative power that lies at our source.

\section{References}

1. Frawley, David (2013) Yoga \& Ayurveda, Self-Healing and SelfRealisation, Motilal Banarsidass Publishers Pvt Ltd, Delhi, India.

2. Frawley, David (2000) Ayurveda and the Mind, Motilal Banarsidass Publishers Pvt Ltd, Delhi, India.

3. Karmananda S, Swami (1986) Yogic Management of Common Diseases, Bihar School of Yoga, Munger, Bihar, India.

4. Mukti bodhananda, Swami (2009) Swara Yoga, Yoga Publication Trust, Munger, Bihar, India.

5. Niranjanananda Saraswati, Swami (2013) Prana \& Pranayama, Yoga Publication Trust, Munger, India.

6. Niranjanananda Saraswati, Swami (2013) Prana Vidya (From the Teachings of Swami Satyananda Saraswati), Yoga Publication Trust, Munger, Bihar, India.

7. Satyananda Saraswati, Swami (1993) Yoga Nidra, Bihar School of Yoga, Munger, Bihar, India.

8. Swami Satyasangananda (2013) Tattwa Shuddhi, Yoga Publication Trust, Munger, Bihar, India.

Your next submission with Juniper Publishers will reach you the below assets

- Quality Editorial service

- Swift Peer Review

- Reprints availability

- E-prints Service

- Manuscript Podcast for convenient understanding

- Global attainment for your research

- Manuscript accessibility in different formats

( Pdf, E-pub, Full Text, Audio)

- Unceasing customer service

Track the below URL for one-step submission

https://juniperpublishers.com/online-submission.php 